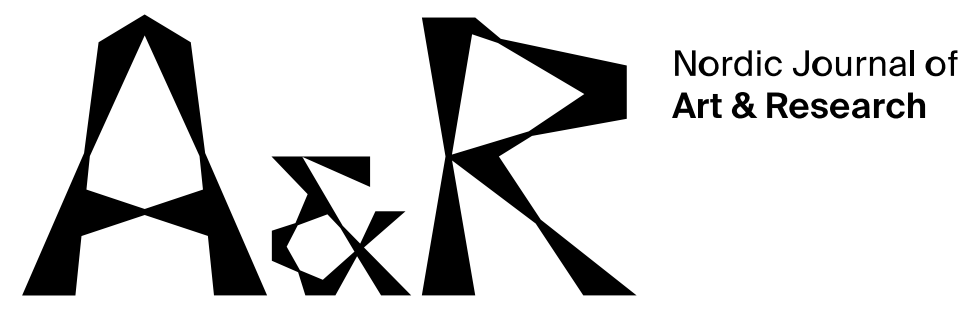

\title{
Jeg håndhilser før jeg penetrerer
}

\author{
Vitenskapelig essay \\ Helene Uri ${ }^{1}$ \\ Norsk barnebokinstitutt
}

\section{Sammendrag}

I dette essayet utforsker jeg hva kunstnerisk utviklingsarbeid kan bety for meg som romanforfatter og som skrivekunstner. Utgangspunktet er ungdomsromanen Stillheten etterpå (2018), og jeg er særlig opptatt av hvordan litterære personer blir til. I teksten henter jeg eksempler fra flere romaner jeg har skrevet, men bakteppet er ungdomsromanen. Jeg uttrykker skepsis til å skrive om egen (skjønnlitterær) skriving, men i løpet av arbeidet med essayet kommer jeg et stykke på vei. For eksempel gjør jeg rede for hvordan skifte av synsvinkel er en metode jeg har nytte av. Men noe forblir uforklarlig, og slik må det være.

Nøkkelord: kunstnerisk utviklingsarbeid, roman, skrivekunst, skjønnlitteratur, synsvinkler, litterære karakterer, barne- og ungdomslitteratur.

\section{Det umulige}

"Å skrive er også å ikke snakke. Det er å være taus." Det er Marguerite Duras som skriver dette (Duras 2014, s. 21). Hun mener at det er "umulig å snakke om en bok man har skrevet, eller en bok man holder på å skrive". Jeg tror de fleste forfattere kan si seg enig i dette, og samtidig ikke. Å være forfatter i Norge på 2000-tallet handler for de aller fleste av oss om to ting: skrive noe og snakke om dette noe etterpå. En gang tellet jeg. Fra romanen Hålke (2016) kom ut i september og til jeg tok juleferie, snakket jeg om den 53 ganger. Men snakke betyr så mangt, å presentere boken i en bokhandel, å snakke om den på et bibliotek, å bli bokbadet på

\footnotetext{
${ }^{1}$ helene.uri@barnebokinstituttet.no, helene uri@hotmail.com
} 
en festival, å gi et avisintervju. Man dykker kanskje ikke så dypt ned i boken, man viker ofte tilbake for å svare på spørsmål om "budskapet" eller "tematikk", man stritter imot og er redd for å snakke den i hjel, å avsløre hvordan man har tenkt og arbeidet. Å snakke lenge og skånselløst ærlig om bøkene sine gjøres ikke mange ganger i løpet av en bokhøst. Ikke ellers heller. Kanskje fordi Duras har rett: Det er umulig.

De gangene jeg snakker mest ærlig og hudløst om å skrive, om min egen skriving, er når jeg holder skrivekurs. Det gjør jeg én gang, av og til to ganger, i året. Modellering av litterære skikkelser er alltid et tema på mine skrivekurs. Med andre ord snakker jeg om det jeg nå prøver å skrive om. Men å skrive om egen skapeprosess har jeg veket tilbake for. Tale er flyktig og ufarlig. Jeg sier ordene, og kanskje fester noen av dem seg hos kursdeltagerne. Kanskje skriver noen ned det jeg sier, men da er det ikke lenger mine ord. Tale er trygt. Man kan moderere seg, tilføye kroppsspråk og intonasjon for å nyansere, for å holde det bastante og entydige på trygg avstand. Man kan til en viss grad bevare det gåtefulle. Skrift er permanent og truende. Ordene står nakne der på skjermen, på papiret, og de forsvinner ikke. Skrift binder. For Duras er også tale umulig. For meg er tale mulig, men skrift har foreløpig vært umulig. $\AA$ reflektere i skrift over egen skriving - alt i meg protesterer. Derfor er det ikke kokettering når jeg understreker at dette er et essay, et essay i sin opprinnelige betydning. Un essai: et forsøk. Et forsøk på å gjøre det umulige. Og til og med et forsøk på å være oppriktig og - enda verre - konkret.

Og årsaken? Den finnes i stillingsbeskrivelsen min og heter kunstnerisk utviklingsarbeid. For tiden er jeg ansatt i en professor II-stilling ved Norsk barnebokinstitutt, og jeg har skrevet ungdomsromanen Stillheten etterpå (2019) som det Program for kunstnerisk utviklingsarbeid kaller "et offentlig tilgjengelig kunstnerisk produkt" (Norsk barnebokinstitutt 2019). Dette essayet er et annet ledd i mitt kunstneriske utviklingsarbeid, nemlig det som videre beskrives som "en eksplisitt refleksjon rundt utviklingen og presentasjonen av kunstproduktet". Essayet er altså en innenfra-betraktning. Det er et blikk fra mitt perspektiv om mitt perspektiv som skrivekunstner, slik jeg har forstått formålet med kunstnerisk utviklingsarbeid, uttrykt for eksempel her: "Kunstnerisk utviklingsarbeid gjøres ut fra og gjennom kunstnerisk arbeid, og formidler dermed innfallsvinkler og erfaringer spesifikt fra dette ståsted" (Malterud 2012, s. 1). Gjennom dette essayet ønsker jeg å utforske hvordan litterære personer blir til. I teksten henter jeg eksempler fra flere bøker jeg har skrevet, men bakteppet er refleksjon rundt tilblivelsen av ungdomsromanen. Teksten handler primært om de to hovedpersonene i denne romanen, Ada og Odd-Erik, og prosessen som førte frem til dem. 


\section{Forsøket}

Mitt essay er et sytøy der flere sømmer møtes. Jeg har skrevet en personlig tekst om egen praksis og poetikk, men det er også en tekst som noen steder gir seg ut for å være en reflekterende, om enn ikke vitenskapelig, tekst. Dessuten har jeg ønsket å skrive et pedagogisk stykke tekst, en tekst som kan brukes av skrivekunststudenter.

Når jeg hører om andre forfatteres måte å skrive på, eller leser bøker og artikler om kreativ skriving, tenker jeg oftest at dette ikke vil fungere for meg. Andre forfatteres metoder fortoner seg som rigide regler eller som løssluppen nonsjalanse. Det er nokså sjelden jeg jubler over et skriveråd og begynner å følge det. Men det hender. Derfor leser jeg med grådighet, en egoistisk begrunnet grådighet, for innimellom hender det. Og uansett lytter og leser jeg med nysgjerrighet. Jeg synes det er fascinerende hvor ulike måtene en forfatter kan nærme seg skrivingen på, er. Jeg synes det er fascinerende å kikke på vrangen av litterære sytøy, lære mer om hvordan andre fester trådene og om de tråkler først eller begynner rett på atterstingene og de franske knutene.

Dette er min måte, et essay om det umulige, som kan leses med grådighet eller bare med nysgjerrighet.

\section{Boken}

Stillheten etterpå er en roman, primært beregnet på unge lesere, kanskje særlig elever i videregående skole. Ada, som er bokens ene hovedperson, er seksten år og elev i første klasse på en videregående skole. Odd-Erik, den andre sentrale karakteren, er tjuefem år og nyutdannet lektor. Vi møter dem idet skoleåret starter. Det viser seg nokså raskt at Odd-Erik ikke er særlig vellykket som lærer. Han leser klassen dårlig, og i sin iver etter å komme elevene i møte mister han respekt og autoritet. Flere av elevene gjør narr av ham, og etter en stund er timene hans bare bråk, uro, kaos. Ada deltar ikke aktivt, men hun gjør heller ikke noe for å hindre det som skjer. Det kulminerer med at noen av Adas venninner nærmest lurer Odd-Erik til å posere sammen med dem på bilder som lett kan misforstås - og det er nettopp det som skjer. Odd-Erik suspenderes, og høstterminen avsluttes på tragisk vis.

\section{Kimene}

Det er vanskelig å si akkurat hva en bok begynner med, hva som fører med seg at jeg begynner å skrive. Det kan være en scene (en gruppe mennesker, voksne og barn, spiser et overdådig måltid i en have med bugnende trær - det var kimen til Den rettferdige (2009)). Det kan være en vag idé (hva med å skrive om ikke-valget, det å ikke foreta seg noe, som fører til at mennesker blir i noe ubehagelig i år etter år - det 
var kimen til Hålke) eller en klar idé (jeg vil skrive om kameraderi i akademia - det var kimen til De beste blant oss (2006)) eller spørsmål (Hvordan oppstår vold i nære relasjoner - det var kimen til Fordi jeg elsker deg (2015)). En sjelden gang er store deler av boken på plass før skrivingen tar til (en god venninne spiste ormekurtabletter for hund i stedet for solhatt - som var startpunktet for Mamma morgenheks (2008)).

Kimen til Stillheten etterpå var et ønske om å skrive om skolen, sett fra både elevers og læreres synsvinkel. Startpunktet var ikke annet enn en arena. Nokså tidlig oppdaget jeg at jeg ville skrive noe om gruppedynamikk, og jeg skjønte at boken skulle handle om en lærer som ikke fikk det til, og en elev som bevitnet det uten å foreta seg så mye, om en lærer som ble utsatt for mobbing og en elev som passivt deltok ved å ikke handle. Det var omtrent det jeg tenkte i de første fasene. Men det jeg tenker så tidlig, blir ofte ikke med videre. Liv Køltzow har sammenlignet disse første famlende skrittene med å bygge et stativ (Andersen 2008, s. 326), og det er en metafor jeg umiddelbart kjenner meg hjemme i: Man trenger noe å henge teksten på ellers får man ikke begynt. Så får man heller rive stativet etterpå. Eller bygge et helt nytt. I prosessen med Stillheten etterpå tok jeg med meg både skolen som arena og ideen om å utforske gruppedynamikk videre.

\section{Character is plot}

Menneskene som skal bebo teksten, må tidlig på plass. Før jeg kan gå videre med hva som skal skje i teksten, må jeg finne ut hvem det skal skje med. For trass i tankene jeg gjør meg på forhånd om handling og hendelser, er det de litterære personene som i stor grad bestemmer hva som skal skje i teksten, og hva slags tekst det skal bli. "Character is plot", sa visstnok den engelske forfatteren Henry James en gang. Og jeg er enig med ham. Om ikke godt utviklede karakterer er handling, så legger de i aller høyeste grad opp til handling.

Før jeg begynte å skrive skjønnlitteratur, ville jeg antagelig ikke ha forstått James' utsagn. For jeg trodde at alle forfattere planla et detaljert plot, for deretter å strø sine personer ut i det. Jeg mistrodde forfattere som påstod at deres litterære personer bare satte i gang med å foreta seg ting på tvers av det forfatteren hadde planlagt. Disse tankene gjorde jeg meg mange år før Kjersti Skomsvold begynte å skrive, men skildringen av hvordan hovedpersonen Mathea overtok skrivingen i Skomsvolds første roman, er noe jeg den gangen garantert ville ha fnyst av: "Da jeg hadde skjønt hvem hun var, var det som om hun tok over skrivinga, og hva som helst kunne skje" (Skomsvold 2019, s. 43). Mens jeg ennå hadde skrevet utelukkende faglitteratur, ville jeg ha vært overbevist om at dette var løgnaktig imagebygging fra Skomsvolds side. Problematisk og nokså provoserende. Men jeg hadde ikke arbeidet lenge med det 
som skulle bli min debutroman for voksne, Dyp rød 315 (2001), før jeg innså at det faktisk var akkurat sånn. Jeg leste Skomsvolds tekst med én gang den kom ut, og jeg nikket bekreftende. Under skrivingen av min første skjønnlitterære tekst erfarte jeg at da jeg først fikk taket på hovedpersonen min, Gina, begynte hun å gjøre en rekke ting som jeg ikke hadde forutsett. Og like ofte opplevde jeg at hun ikke alltid ville gjøre det jeg hadde sett for meg. Gina var sta og egenrådig og opponerte mot mine planer. Mystisk? Nei, ikke egentlig. Forklaringen på noe som for meg på et tidspunkt syntes svevende og overnaturlig, har en ytterst jordnær forklaring.

\section{Litterære skikkelser har egenvilje}

Det er like enkelt som det er komplisert. Hvis jeg får personene mine til å leve, ja, så lever de. Og som vi alle vet, er det ikke alltid våre medmennesker gjør akkurat det vi vil at de skal gjøre. Min påstand er at litterære skikkelser har en egenvilje; forutsetningen er at de er godt konstruert. Sentrale litterære skikkelser, kall dem gjerne bokens hovedpersoner, må og skal ha egenvilje. De perifere kan imidlertid fint leve på boksidene uten å ha et komplisert sjeleliv.

Jeg ser for meg Køltzows stativ som et klesstativ, en slags stumtjener. Hvis jeg skulle bruke stativmetaforen hennes videre, kan jeg si at å lage et plott uten personer, er som å prøve å skreddersy plagg uten å vite hva slags mennesker man syr til. Man henger stoffet på stativet, og det gir en slags idé om det man skal sy. Men ikke noe mer. Et grovmønster kan man få til, men det må justeres kraftig når man ser kroppsfasongen til den man syr til. Den famlende begynnelsen for meg er et vekselbruk mellom å skrive frem personene og skrive frem hva som skal skje. Personer og handling er gjensidig avhengig av hverandre, men handlingen er hos meg i mye større grad avhengig av personene enn motsatt.

I de første fasene av arbeidet med Stillheten etterpå hadde jeg en idé om at eleven skulle være en lederskikkelse, en som hadde makt og mulighet til å stoppe klassens trakassering av læreren. Men eleven min, Ada, utviklet seg til å bli en mer tilbakeholden type, og jeg måtte legge om kursen kraftig ettersom hun ble tydeligere for meg. Det jeg hadde sett for meg av et mulig handlingsforløp, passet ikke til Adas personlighet, slik hun vokste frem.

Og da er det Ada som vinner. Alltid. Det er alltid de litterære skikkelsene som går seirende ut hvis det er en konflikt eller motsetning mellom dem og handling.

For jeg vet sjelden nøyaktig hva jeg vil med en roman. Jo, det finnes en vag tanke om retning i noen tilfeller, i andre ikke engang det. Det er sånn det skal være. Det er 
sånn det er å skrive for meg. "Det er boken som presser seg frem", skriver Duras (2014, s. 21). Hun er opptatt av fortellingen som en organisme, som lever sitt eget liv, delvis løsrevet fra forfatteren.

Skrivingen er det ukjente. Før man skriver vet man ingenting om det man kommer til å skrive. [...] Det er det ukjente i en selv, i hodet, kroppen. [...] Hvis man visste noe om det man er i ferd med å skrive før man skriver, ville man aldri ha skrevet. Det ville ikke være verdt det. (Duras, 2014, s. 46)

\section{Ut av skyggene}

Mine litterære personer starter sitt liv som grå skygger, kanskje har de én eller to særegenheter som jeg vet om fra starten, kanskje er de tiltenkt en slags funksjon i teksten, en rolle de skal spille i handlingen. Men som forfatter er man vankelmodig, og skikkelsenes egenskaper skifter uopphørlig. Likevel, går det som man håper, vokser de frem og kommer ut av skyggene. Jeg har skrevet om denne første fasen i romanen Rydde ut (2013). Kan hende var det omtrent sånn hovedpersonen Ellinor ble til, og kan hende er dette den beste beskrivelsen av hvordan mine litterære personer blir skapt, Ada inkludert:

Jeg satt med en notisbok, slik jeg alltid gjør når jeg skal begynne på et nytt bokprosjekt, kikket på notater jeg har tatt tidligere, forsøkte å rydde opp i ideene, samle dem, koble dem. Katten lå som en ball i vinduskarmen og stirret fornærmet ut på regnet. Kunne hovedpersonen min - hva hun nå skulle hete - være filolog? Språkviter? Jeg bet i enden av pennen, plasten ble splintret mellom tennene mine. Katten snudde seg så vidt, kastet et gult blikk på meg før den igjen konsentrerte seg om gaten. Regndråpene trillet nedover rutene, laget loddrette, seige veier av vann. Mellom to våte striper dukket hun opp. Som en skygge, uten kjøtt og blod, uten ansikt, men likevel var hun. Kunne hun hete Ellinor? Ja, det var det hun het: Ellinor Smidt. Hun elsker duften av kaffe, og hun vet at hun kunne ha vært en god mor. Nå satt hun like ved meg, i stolen som står ved siden av skrivebordet, der katten pleier å ligge når den ikke er på en av de faste utkikkspostene. Hun kom til å få kattehår på buksen, ikke det at det er noe hun ville ha brydd seg om. Hun er nok ganske skjødesløs med utseendet sitt. Ellinor fnøs. Katten snudde seg igjen, men denne gangen så den forbi meg og mot stolen ved siden av skrivebordet. Pennen stod ennå i munnen min, mellom jekslene på høyre side, det knaste i den igjen, en splint løsnet og ramlet ned ved siden av tungen, jeg 
tok pennen ut av munnen, fjernet plastsplinten. Nå ja, kanskje ikke skjødesløs, men hvis Ellinor vil sitte i en stol, så lar hun seg ikke stoppe av noen kattehår. De kan børstes bort. Hvis hun gidder. (Uri 2013, s. 13)

Avsnittet er fiksjon - for eksempel så gnager jeg sjelden på penner - men det jeg beskriver, ligner ganske mye på virkelighetens skriveprosess. Litterære personer kan dukke opp fra intet, og i begynnelsen er de bare skygger, uten kjøtt og blod. Da jeg begynte med Stillheten etterpå, visste jeg bare at det skulle være to hovedpersoner: en elev i videregående skole og en lærer. Jeg visste også tidlig at de ikke hadde samme kjønn. I de første skriveøktene var læreren en kvinne og eleven en gutt, antagelig fordi jeg som voksen forfatter på et tidlig punkt i skrivingen identifiserte meg mest med den voksne. Etter et par skriveøkter byttet jeg kjønn på de to.

Mens jeg skrev Stillheten etterpå, førte jeg en upretensiøs, halvhjertet logg. Loggen var ment som en hjelp for refleksjonene rundt den kunstneriske prosessen. At loggen ble upretensiøs, skyldes at jeg ville unngå å legge føringer om form og kvalitet som ville kunne ha hindret meg i de umiddelbare kommentarene jeg var ute etter. Loggføringen lettet ikke den skjønnlitterære skrivingen, og det var heller ikke intensjonen. Jeg har liten erfaring med logg, og det ble ingen udelt positiv opplevelse. For meg ble det klart ganske tidlig at å skrive både et manus og en tekst om manus, ikke er en problemfri kombinasjon. Loggen endte opp som temmelig halvhjertet, uten at det var meningen. Likevel inneholder den underveis-observasjoner som jeg nok ellers lett kunne ha glemt. Om kjønnet til de to hovedpersonene skriver jeg:

Læreren er av hankjønn. En mann. Med skjegg?? Nei. Ung mann. En mer spenstig konstellasjon??? Makt \& avmakt. Sånn som jeg forestiller meg boken, vil maktbalanse være viktig. Mer spennende å gå inn i et forhold der den sterke part er en jente på 16 år? Og den mobbede part er en voksen mann? Tja. Foreløpig er jeg der. Holder fast på det inntil videre ...

Og litt senere har jeg notert:

Med læreren som mann er voksenpersonen iallfall lenger unna meg. OK. Jaha. Er det et mål? Vet ikke. Kanskje? Kommer jeg dermed nærmere eleven? Tja. Kanskje målet bare er at de to hovedkarakterene har hvert sitt kjønn? Men hvorfor?? Det kjennes riktig. Ja. Lander der. Til man flyr videre. Kanskje. Umulig å vite hvor jeg skal. 


\section{Hvor kommer de fra? Utenfra}

Jeg har lært meg å skrive på toget, på hotellet og på venterommet. Ved de oppfellbare bordene på flyet. Jeg noterer under middagen, under bordet eller på toalettet. Jeg skriver på trappa til et museum, på kafeen, i en bil parkert i sidefeltet. Jeg noterer på papirbitene, i notatblokkene, på postkortene, på huden på hånden, på serviettene, i bokmargene. Som oftest er dette korte setninger, tablåer, men noen ganger skriver jeg av utdrag fra avisene. Det hender jeg blir forført av en skikkelse klekket ut fra folkemengden, og da tar jeg en avstikker fra marsjruten min for å følge denne skikkelsen en liten stund, for å sette fortellingen i gang.

(Tokarczuk, 2018, s. 22)

Dette er ordene til Olga Tokarczuks jeg-person i romanen Løperne. De kunne vært mine: den gode besettelsen ved å skrive og det nødvendige tyveriet fra omgivelsene. Og det er det siste punktet det skal handle om. Forfattere har gjort det til alle tider; de har brukt sine omgivelser og erfaringer. Hva annet skulle vi ha brukt? Vi bruker en beruset mann vi så i forbifarten på trikk nr. 12, vi bruker samtaler med våre nærmeste venner, eller vi følger etter en mann i menneskemengden. Vi trengte ikke debatten om virkelighetslitteratur for å slå fast at noen litterære personer er basert på mennesker forfatterne kjenner. Mange skriver med utgangspunkt i virkelighetens mennesker, men skriver likevel på en måte som ikke skaper etiske dilemmaer.

For meg er det etiske grunner til at jeg ennå ikke har bygget noen av hovedpersonene mine på virkelige mennesker. Men det dreier seg ikke bare om etikk, det dreier seg også om min litterære metode: Jeg har ikke kjent noen sterk trang til å skrive om virkelighetens mennesker, og i den grad jeg har prøvd, så har fiksjonen i løpet av få arbeidsdager vunnet over fakta, og personene er blitt ugjenkjennelige for alle, inkludert den opprinnelige modellen. Men også i forfatterskapet mitt er det visse unntak.

I universitetsromanen De beste blant oss er flere perifere personer, som kanskje bare opptrer i ett eneste avsnitt, kalkert over virkelighetens ansatte ved Universitetet i Oslo. Personene er i de fleste tilfeller forvrengte utgaver av seg selv, karikerte og overdrevne, gjerne med navn som er varianter av deres egne navn. Disse er lett gjenkjennelige for folk med kjennskap til norsk akademisk liv. Jeg leker med fakta og fiksjon i denne boken, og kanskje øker det følelsen av realisme. På denne måten pumper jeg rett og slett opp den fiktive realismen, og den tilsiktede effekten er at det er vanskeligere å skille mellom sant og usant, fiksjon og virkelighet. 
Prosjektet i romanen Rydde ut var å finne mer ut om min egen farfar. I denne romanen opptrer han og en rekke andre av mine slektninger - de aller fleste av dem er døde - under eget navn, og det som skrives om dem, er iallfall i nærheten av en sannhet. Dette er også den eneste av mine romaner der jeg-personen er mer eller mindre identisk med forfatteren. Men selv ikke i hverdagslige situasjoner klarer jeg å dy meg: Som nevnt biter jeg ikke i stykker penner. Kunsten, fiksjonen, det som kler helheten overstyrer virkeligheten. Det sanne i en roman er ikke en detaljtro gjengivelse av virkeligheten:

Jeg tar på meg den svarte boblejakka, men jeg skriver at jeg tar på meg den blå kåpa, så blir det noe litt høytidelig over å reise inn til byen for å hente barna, og å-ene i "blå" og "kåpe" kan hilse på hverandre.

(Skomsvold 2019, s. 68)

I romanen Honningtunger (2002) brukte jeg en metode som jeg med hell tidvis har brukt for å sparke i gang arbeidet med å skape litterære personer. Romanen har fire kvinnelige hovedpersoner. For minst to av dem tok jeg utgangspunkt i venninner. Men jeg brukte særtrekk ved venninnene mine bare som et springbrett for fiksjonen. Så snart jeg var i gang, fordampet det som måtte ha vært av likheter, og i den trykte romanen finnes det ikke lenger spor av mine to venninner. De har begge lest boken, og ingen av dem har noensinne nevnt noe om noen likheter. De er ennå uanende om at de i noen uker var modeller og igangsparkere.

Personene vi skaper, er selvfølgelig i større eller mindre grad et resultat av mennesker vi har møtt i løpet av livet. Det er ikke alltid vi er klar over det engang, og ofte vil en litterær person være en mosaikk av forskjellige mennesker, ett trekk fra gymlæreren fra ungdomsskolen, et par fra faren din og noen fra han håpløse naboen. Sånn er det også i Stillheten etterpå. Odd-Erik har trekk fra en lærer jeg hadde på ungdomsskolen, og jeg har tenkt mye på en annen lærer fra den tiden, som ikke deler personlighetstrekk med Odd-Erik, men som gjennomgikk noe av det samme marerittet i klasserommet, som han gjør. I loggen skriver jeg:

I går gravde jeg frem klassebildet fra åttende klasse. Der er vi alle sammen. Der er jeg. Jeg smiler, ser på det som er meg nå, og tennene er større og nesen en knapp. Bildet er opprevet og skittent på den ene siden, på baksiden er det hilsener. Stirret lenge på ansiktene som en gang var kjente og dagligdagse, og som nå sitter fast på mennesker jeg sjelden ser. Jeg prøvde å fremkalle timene med [navn], prøvde å huske 
hvordan det var å sitte der i klasserommet og se henne lide. Prøvde å huske hvorfor jeg ikke gjorde noen ting.

Odd-Erik ligner ikke på læreren fra den gang. Men han ligner ganske mye på en jeg kjenner, eller kjenner til. Mange av Odd-Eriks idiosynkrasier hentet fra en person ytterst i min bekjentskapskrets, og jeg har aldri før hatt en virkelig person så langt fremme i bevisstheten når jeg har laget en litterær person. Jeg skriver:

Jeg tenker stadig hva ville $Y$ gjort i denne situasjonen? Hvordan ville $Y$ ha reagert? Hvilke ord ville $Y$ ha valgt? Liker det egentlig ikke, tror jeg skammer meg litt. Men jeg vet at $Y$ aldri ville ha kjent igjen seg selv. OddErik og $Y$ ville trolig ikke ha likt hverandre særlig godt engang!

\section{Hvor kommer de fra? Innenfra}

Andre mennesker kan inspirere eller være modeller, men den viktigste kilden til mine litterære personer er meg selv. Merete Morken Andersen understreker flere steder i Skriveboka (2008) at vi som skrivere må rette blikket både utover og innover. Vi observerer andre, og vi dukker inn og ned i oss selv.

Og for meg er den innadrettede bevegelsen langt viktigere. Skal man skrive god skjønnlitteratur, må man være ubarmhjertig åpen med seg selv. Skal man skrive god skjønnlitteratur, må man våge å grave dypt ned i seg selv, hente opp igjen det man finner, og våge å la lyset skinne på det. Uansett om man finner sjalusi, misunnelse, hat eller forfengelighet, følelser man egentlig ikke vil være ved at man har. Det er nettopp da man skal løfte dem frem i lyset og studere dem fra alle kanter. Hva gjør meg sjalu? Hvordan kjennes det? Hvordan kjennes det i kroppen?

Da jeg arbeidet med romanen Engel av nylon (2003) og skulle skrive om en mor som (mente at hun) ikke elsket sin datter, var det hos meg selv jeg fant mest interessant stoff. Jeg gjorde research, leste forskningsartikler, men det var først da jeg lette etter situasjoner der jeg kunne kjenne at jeg ikke likte barna mine, var lei av dem, hadde mest lyst til å skylle dem ned i toalettet, at jeg fikk taket på personen Beate. I stedet for å skyve unna de følelsene (som alle småbarnsforeldre kjenner på fra tid til annen), dvelte jeg ved dem, prøvde å tilbakekalle avskyen og følelsen av distanse.

På samme måte har mine egne erfaringer vært hovedkilden til både Odd-Erik og Ada i Stillheten etterpå. Odd-Eriks tendens til å feie vanskelighetene under teppet, innbille seg at hvis man ikke snakker om noe, så forsvinner det. Hans behov for kontroll i hverdagen. Hans ønske om å bli likt. Hans glede av å stå foran en forsamling som lytter til ham. Alt dette er mitt. Alt dette har jeg funnet i meg. Men i Odd-Eriks tilfelle er 
det forstørret og forvrengt. Adas brennende ønske om å bli akseptert av de kule. Hennes unnfallenhet og feighet. Hennes tilbøyelighet til å dagdrømme. Mitt, mitt, mitt. I forstørret og bearbeidet form.

Men selvsagt er dette høyst gjenkjennelige menneskelige trekk. Allmenngyldig. Lite originalt. Det er ikke akkurat unikt at jeg finner dette når jeg bruker gravemaskin i mitt indre landskap. Men at jeg har funnet det hos meg selv, gjør at jeg kan skrive om det med troverdighet og med den personlige vrien som blåser liv i Odd-Erik og Ada. Men jeg skriver ikke meg. Jeg skriver Odd-Erik og Ada.

\section{Bak meg står en leser og smugtitter ned i manus}

Når man skriver, kan man ikke tenke på at leserne dessverre har en lei tendens til å koble forteller og forfatter. Jeg kan ikke tillate meg å bekymre meg for om leserne vil lempe mine romanskikkelsers sjalusi og smålighet, forfengelighet og feighet tilbake til meg. Når jeg skriver, skal det ikke være noen andre i prosessen enn meg selv og teksten som vokser frem. Skomsvold (2018, s. 93) sier det på denne måten: "Jeg må bli fri fra tanken på leseren, jeg vil ikke tenke på leserne underveis, skriften er ikke henvendt til noen." For meg betyr det likevel ikke at leseren aldri er med når jeg skriver. Det ville vært en arrogant uttalelse. Usann også. Med ujevne mellomrom kikker jeg opp fra teksten, og av og til står det en tenkt leser bak meg og smugtitter ned i manus. Jeg legger hendene beskyttende over skjermen, for hun får ikke lov til å lese. Ikke ennå. Men jeg snur meg og forsikrer leseren om at jeg ikke skal glemme henne. Ikke helt. For selv om teksten er bare min nå, skal jeg etter hvert slippe den. Da er den like mye til henne som til meg. Når jeg skriver bøker for barn og ungdom, kan det nok hende at jeg litt hyppigere kaster et blikk over skulderen for å minne meg selv om hvem jeg skriver for. Men mottagerbevissthet må aldri føre til sensur og redsel for å "avsløre seg", bare til bedre valg. En barnebok er beregnet på lesere som kognitivt står på et annet sted enn voksne lesere og den voksne forfatteren. Det får konsekvenser for hvordan jeg former teksten, både innholdet og språket. Avstanden mellom forfatteren og leseren er lang, i alder, kunnskap og erfaring. Voksen forfatter og unge lesere møtes i de litterære skikkelsene, som ofte er barn, med barns øyne på verden, men med et mer voksent språk og mer modne refleksjoner (se Ørjasæter 2018). Barnelitteraturens barn er fiktive barn på mer enn én måte.

Stillheten etterpå er skrevet for unge lesere. Avstanden mellom meg som forfatter og mine lesere er kortere enn når jeg skriver for småbarn. Småbarns verden er en bitte liten verden. Jeg trenger ikke å holde meg i den, for litteraturen kan åpne og utvide denne verdenen. Likevel: Når jeg skriver for mindre barn, tar jeg selvsagt både 
innholdsmessige og språklige hensyn. Men for meg er det liten forskjell mellom å skrive en ungdomsroman og å skrive en roman for voksne. Hele forskjellen kan samles i ett punkt: de litterære skikkelsene. Det handler som oftest om unge mennesker i bøker spesielt beregnet på unge mennesker. Så også i mine ungdomsromaner. Og når perspektivet tilhører et ungt menneske, for eksempel Ada, så gir det automatisk naturlige føringer for språk, for kunnskaper eller manglende kunnskaper, for erfaringer eller manglende erfaringer. Ada på seksten år ser verden på en annen måte enn for eksempel Ellinor på noen og førti i Rydde ut. Ada på seksten har en annen språkføring enn for eksempel Edvard på nittién i Den rettferdige.

\section{Ibsen, Lukeman og jeg}

I dette essayet har jeg påstått at for å kunne skrive en skjønnlitterær tekst må personene stå levende for meg. Ja, mer enn det: De må leve, puste selv, tenke, føle, handle. Et stykke uti skriveprosessen må jeg vite hva de litterære skikkelsene vil foreta seg i en gitt scene. For å sette det på spissen: Jeg må faktisk vite nøyaktig hvordan hovedpersonene ville ha oppført seg og reagert, hva de ville ha sagt, $i$ enhver tenkelig situasjon.

Jeg har hørt en anekdote om Henrik Ibsen; jeg vet ikke om det stemmer eller ikke, men det spiller ingen rolle. Anekdoten dreier seg om hvordan Ibsen nærmet seg sine dramatiske personer: Han skrev gjennom skuespillene tre ganger. Etter den første gangen kjente han personene som om han hadde vært på en kort togreise med dem, etter andre gangs gjennomskriving kjente ham dem som om de hadde vært på samme kurbad i noen uker, og etter at han hadde skrevet gjennom for tredje gang, var det som om de hadde kjent hverandre hele livet. For meg gir dette fullkommen mening. Når jeg er godt i gang med skrivingen, dypt inne i historien, så er ikke bare målet at jeg skal kjenne hovedpersonene som om jeg har kjent dem hele livet, det er også realiteten. Det er en forutsetning for at jeg får historien til å sitte, for at jeg kan skrive videre. På samme måte som jeg med litt anstrengelse kan forestille meg hva mine barndomsvenninner eller mine søskenbarn ville ha foretatt seg hvis de ble utsatt for dette eller hint, kan jeg forestille meg hva mine romanpersoner ville ha foretatt seg hvis de ble utsatt for det samme. I en bok om skriving, Lukeman (2003), er det lange lister med spørsmål om hovedpersonene som en forfatter må kunne gjøre rede for: Er personen allergisk? Har personen søsken? Har personen banklån? Sniker personen i kassakø? Jeg iler til og understreker at Lukeman selvfølgelig ikke mener at alt dette skal komme til uttrykk i den teksten man skriver. Det er det bare en bitte liten brøkdel som gjør. Men man skal vite. Foretrekker Odd-Erik kjøttkaker i brun 
saus eller noe dampende hot? Hva slags musikk liker Ada? Kunne Odd-Erik ha sneket på trikken? Er Ada opptatt av merkeklær? Er Odd-Erik?

Jeg tror nok at jeg kunne ha svart på alle Lukemans spørsmål om samtlige av mine romanpersoner gjennom mitt forfatterskap, antagelig ikke nå i ettertid, men iallfall da jeg skrev den aktuelle boken, og var kommet et godt stykke på vei. Poenget er ikke å ha alt klart for seg, men at man kjenner sine fiktive personer så godt at man tenke seg svarene.

\section{En pinlig lek med adjektiv}

Spørsmålet er hva jeg gjør for å komme meg til dette punktet. Hvor starter jeg? Det starter med at jeg øyner noe langt der inne i skyggene. For å dra dette "noe" frem og ut, tvinger jeg meg til å fastslå banalitetene: et navn, et kjønn, en alder. Det kjennes ikke alltid riktig, og ofte viser det seg å være feilslått, men det er én måte å bygge Køltzows stativ på (Andersen 2008, s. 326).

Jeg har bestemt meg for at hovedpersonene i Stillheten etterpå er en mannlig lærer og en kvinnelig elev. I loggen står det rett og slett:

Jeg har døpt læreren Erik. Han er 24 år, ferdig med lektorprogrammet ved UiO. Stolt av det! Eleven har jeg kalt Ada. Først prøvde jeg med Ida, men det klang ikke riktig. Helt feil faktisk!!! Ada er 16 år. Så får vi se.

I en notisbok, i hjelpedokumentet, på telefonen, hvor som helst, begynner jeg å notere ned adjektiv som karakteriserer hovedpersonene, biografiske data, kanskje detaljer om utseendet deres, vaner og uvaner. På et tidspunkt har jeg notert følgende om Erik, som i den endelige versjonen av boken blir hetende Odd-Erik:

Bor i sokkelleilighet hjemme hos foreldrene

Har en del guttevenner

Lite erfaring med jenter

Har ikke kjæreste

Litt nerdete

Litt stille

Ivrig på temaer som interesserer ham

Litt verdensfjern

Glad i å gå turer

Interessert i litteratur og sosiologi

Redd hunder 
Fra Rydde ut sakser jeg disse linjene om en tilsvarende tekst:

Dokumentet om Ellinor er hjelpeløst, dødt. Som en katalogtekst. Jeg vet det må være sånn. Det tar tid. Og enten kommer Ellinor til å materialisere seg, eller så er det bare å begynne på nytt. Det hjelper ikke å presse.

Nei, punktene om ham som skal bli Odd-Erik og om henne som skal bli Ellinor, er milevis fra litteratur. Det er notater, pinlige, personlige, skrevet for å slettes, som det nesten er vondt å vise frem. Jeg nærmer meg det umulige. Men de er trinn på veien, som, hvis jeg er heldig, kan hjelpe meg til å skape personene. Betegnende nok er det ofte også slik at mange av karaktertrekkene jeg på et tidlig tidspunkt utstyrer de litterære personene med, ikke blir med videre. Om en av de tre hovedpersonene i romanen De beste blant oss, Pål Bentzen, hadde jeg notert at han hadde "kameleonegenskaper". Dette er det aller første punktet jeg har skrevet om Pål, og jeg anså kameleontendensen som hans viktigste karaktertrekk. Jeg ville ha Pål til å være en mann som alltid snakket andre etter munnen, aldri turte å ha egne meninger. Det eneste som er igjen av dette trekket i den trykte romanen, er at Pål har en egen evne til å herme uttale, til å tilegne seg nye språk aksentfritt.

Det er heller ikke så mange av punktene over som ble med videre, som kjennetegner den endelige Odd-Erik. Som illustrasjon kan jeg sette opp denne statusen, som tydelig viser at mine punkter bare er for å igangsette en prosess (markert ved minustegn (stemmer ikke) og plusstegn (stemmer)):

Bor i sokkelleilighet hjemme hos foreldrene (- Han har egen leilighet) Har en del guttevenner (- Han har så vidt kontakt med én.) Lite erfaring med jenter $(+)$ Har ikke kjæreste (+ og - Han får kjæreste i begynnelsen av boken) Litt nerdete $(+)$ Litt stille $(+)$ Ivrig på temaer som interesserer ham (+og - Tja, det er uansett ikke noe som kommer tydelig frem)

Litt verdensfjern $(+)$ Glad i å gå turer (- Det er mulig, men han går ikke mye turer.) Interessert i litteratur og sosiologi (- Han er først og fremst interessert i norskfaget)

Redd hunder (- Han er likegyldig til hunder) 


\section{Ord føder ord}

Hvis jeg skulle ha brodert et banner med et slagord for skriving, iallfall for min skriving, så ville jeg ha sydd "Ord føder ord". For det er når jeg skriver, selve skapingen skjer. Jeg skriver ikke ned tanker som jeg har tenkt ferdig; det jeg gjør, er å skrive ut halvtenkte tanker og derigjennom tvinges jeg til å tenke videre. I Anders Johansens bok Skriv! Håndverk i sakprosa sies det på denne måten (2018, s. 14):

Mitt faglige virke går for en stor del ut på å lete frem ord, snekre sammen setninger, organisere helhetsvirkninger på en slik måte at jeg synes det holder litterært. Hvis stoffet dermed blir lesverdig, er det vel og bra. Men det er ikke for å presentere et faglig innhold på en spennende måte at jeg legger slikt arbeid i formen. Det er for å vinne fram til dette innholdet.

Litt senere skriver han (Johansen 2018, s. 16): "Det er gjennom strevet med ord og setninger at vi utvikler vårt kjennskap til saken." Johansen snekrer sammen setninger. Jeg ser for meg at jeg broderer et banner og syr en tekst. Johansen skriver om sakprosa. Jeg har samme erfaring med skjønnlitteratur. Jeg kan prøve å planlegge, jeg kan lage lister, jeg kan leke pinlige adjektivleker, jeg kan diskutere det litterære prosjektet med redaktør og ektefelle, men det er ikke før jeg setter meg ned og skriver, at tankene blir klarere og dypere. Skomsvold (2019:19) sier: "[...] for hver setning jeg skriver, oppstår det ti nye, og for hver roman jeg skriver, forstår jeg noe nytt". Jeg sier: Ord føder ord, og etter hvert vokser skikkelsene mine, etter hvert blir de så sterke at de kan bære historien.

Jon Fosse blir i et intervju (Østli 2019) spurt om han har ideer eller lapper på skrivebordet før han begynner på en tekst, og han svarer utvetydig og kontant nei:

Ingenting ingenting ingenting! Jeg vet absolutt ingenting. Jeg vet bare: Nå skal jeg skrive prosa. Da lager teksten sin egen logikk, sine egne personer og historier. [...] Å skrive er en måte å forstå på - og dermed også tenke på. [...] Alt skrives frem fra ingenting. Å komme i gang er det vanskelige, men er du i det, skriver det seg selv.

"Men er du i det, skriver det seg selv", sier Fosse. "Å komme i gang er det vanskelige." Min metode for å komme i gang, for å bringe meg "i det", er å sette opp banale lister. Det fungerer ofte ganske bra. Selv om jeg skammer meg over dem, så nakne og rå og billige som de er. Spekket med innhold, men likevel tømt for innhold. 
Punktene med karaktertrekk revideres fortløpende. For hver gang jeg arbeider med manus, vet jeg mer om personene mine, og punkter slettes og nye kommer til. Et stykke lenger ut i prosessen har jeg føyd til dette på listen om Odd-Erik:

\section{Er enebarn}

Sparsommelig

Rutinemenneske

Og når jeg er godt i gang med skrivingen, har jeg ikke bruk for punktene mer og glemmer dem. Sletter dokumentet, glemmer stikkordene. Skjuler skammen. Og lar ordene føde ord.

\section{Nøkkelscener}

Det finnes styrtfødsler. Det finnes enkle, ukompliserte fødsler. Men ofte tar det tid å få liv i de litterære personene. I Stillheten etterpå tok det lang tid. På et tidspunkt der jeg har jobbet flere måneder med manus, skriver jeg i bloggen:

Erik og Ada er døde. De er bare falske konstruksjoner. Jeg får det ikke til. jeg får dem ikke til. Blir sint. Kanskje jeg skal prøve å skrive en scene med de to, en scene som betyr noe. Mulig jeg finner dem da! Kanskje en klasseromsscene?? En mobbescene? Ja, kanskje ... Erik begynner å bli mobbet av elevene, en scene der Ada ikke tar avstand. Prøver det neste skriveøkt.

Jeg husker situasjonen. Klisjé. Eller i det minste klassisk. En forfatter som stirrer inn i en tom skjerm. En forfatter som ikke kommer seg videre. Som henter te, som sjekker mail, som står fast. I fortvilelse skrev jeg linjene i bloggen om en mulig løsning - en slik løsning jeg kunne ha kommet til å ha anbefalt til andre som stod fast. Linjene forpliktet til å prøve løsningen. Jeg hører min egen skrivelærerstemme: "Det kan virke forløsende å skrive på det stedet i handlingen der noe står på spill for personene. Der det brenner." Av og til er det lurt å høre på læreren. I dette tilfellet hjalp det meg å se Odd-Erik tydeligere. I scenen nektet Odd-Erik å innse hva som skjedde, han prøvde å overbevise seg selv om at han var en vellykket lærer. Dagen etter er loggen mer optimistisk:

Yess. Erik ble mye tydeligere for meg! To scener fra klasserommet. I tredjeperson. Perspektivet er hans. Han er der nå. Erik is alive! I hvert fall er han mye nærmere. Ada har ennå ikke manifestert seg. Aner ikke hvem hun er. Frustrerende. Hun er jo med i scenen, hun tar til og med ordet flere ganger og har fire replikker. Men egentlig er hun ennå ikke til stede. 
Og jeg noterer meg at jeg uten å være meg det bevisst skrev teksten fra Eriks perspektiv.

\section{Replikker - på god vei inn i hodet}

Selv en god stund etter at jeg fant Odd-Erik, eller Odd-Erik og jeg fant hverandre, var Ada bare en diffus skygge:

Hvem er Ada? Ada fungerer ikke. Hun er stiv og mekanisk, og jeg skjønner meg ikke på henne. Hvem er hun? Hva vil hun? Hva tenker hun på? De biografiske trekkene er på plass, men ikke mye mer. Jeg må få henne til å leve, eller jeg må revurdere hele jenta.

Det var ikke bare jeg som ikke syntes Ada fungerte. Bak meg når jeg skriver, står ikke bare en tenkt leser, men også en høyst levende redaktør; i dette tilfellet var redaktøren Kaisa Hoel i Gyldendal: "Ada må få mer plass", skriver hun til meg flere måneder etter notatet i loggen, og senere i samme mail:

La Ada interagere mer, både på skolen, med venninnene og på fest. Hun er i stor grad en observatør nå, men vi blir nok bedre kjent med henne om hun er med på det som skjer - snakker med noen, gjør noe, havner i noen situasjoner - kanskje særlig med Sergej [Sergej er gutten Ada er forelsket i, og som hun etter hvert blir sammen med].

Min medisin er ord. Det redaktøren foreskriver, interaksjon, er også en effektiv medisin. Den ene medisinen utelukker ikke den andre. Tvert imot. De bygger på hverandre. Det er vanskelig å skrive flere scener hvis Ada-språket ikke sitter, hvis jeg er usikker på hvem Ada er. Ada må komme til orde i flere replikker, har jeg notert i loggen: "La jenta snakke! Kanskje hun har noe å melde!" Men det er like vanskelig å skrive frem Ada og finne stemmen hennes hvis hun ikke skal foreta seg noe. Ada må ha noe å snakke om også! Løsningen ble å svelge store doser av begge medisintypene.

Og i scenene jeg supplerte med, prøvde jeg å la Ada snakke mest mulig. Direkte tale kan være livgivende for halvdøde litterære skikkelser. For når de litterære personene formulerer seg - eller rettere sagt når jeg lar dem gjøre det - blir de tydeligere. Når jeg lar dem lage setninger og velge ord, så må jeg forflytte meg inn i hodet deres. Hvilke ord bruker denne personen? Hvordan skal hun si dette? Er hun direkte eller mer nølende? Bruker hun slang, dialekt eller mye fremmedord? Er hun velformulert eller plump? 


\section{Synsvinkel - rett inn i hodet}

Når jeg jobber med en litterær person, når jeg lar ham eller henne handle og reagere, så vokser personen frem for meg, litt etter litt. For meg skjer dette mye lettere om jeg lar handlinger og reaksjoner filtreres gjennom personen. Replikker er én mulig måte. En mer drastisk, men til gjengjeld også mer effektiv, måte er å skrive hele teksten i jeg-form. Når jeg skriver i førsteperson entall, kryper jeg inn i hammen til en annen, hører med en annens ører, ser med en annens øyne og snakker med en annens munn. Jeg beskriver det som høres og ses og oppleves, med en annens ord, og da materialiserer denne personen seg ofte. Personer som jeg har strevd med å se, med å forstå, med å få til å leve, kommer mot meg. De puster og lever - og har sin egen stemme. Ofte. Ikke alltid.

\section{Mild magi}

Mange av mine ferdige romaner er skrevet i tredjeperson, men jeg har brukt førstepersonskriving som en teknikk underveis i alle sammen.

For eksempel er Den rettferdige (2009) en roman i tredjeperson. Det er omfangsrik roman med et nokså komplekst persongalleri til meg å være. Synsvinkelen er personal, så leserne får etter tur innblikk i flere personers tankeverden. Jeg arbeidet lenge med å finne frem til hovedpersonene, få dem til å leve og agere. En av metodene jeg brukte, var nettopp å skrive i førsteperson. Flere av de sentrale personene har vært innom jeg-formen før de endte som han og hun igjen.

Personal synsvinkel i tredje person gir samme muligheter til å trenge inn i de litterære skikkelsenes tanker som første person entall. Jeg kommer like tett på skikkelsens tanker, følelser og erfaringer om jeg skriver "Han var kaffetørst og underlig nedtrykt" som "Jeg var kaffetørst og underlig nedtrykt". Det er ikke der forskjellen ligger.

Forskjellen ligger i at det lille pronomenet jeg presser frem denne personens språk og perspektiv. Det er som mild magi hver gang. Jeg behøver ikke å skrive mange avsnitt i jeg-form før jeg er krøpet innunder huden, inn i denne personen. Jeg kikker ut på verdenen med hans eller hennes øyne, fremfor å betrakte personen utenfra. Språket blir annerledes, ordvalget er et annet, selv syntaksen påvirkes - i tillegg til at hendelser tolkes og oppleves på vidt forskjellig vis. Som en aldrende mann da jeg-et var Edvard, som en middelaldrende kvinne da jeg var Marianne, som en middelaldrende mann da jeg var Karsten, og som en yngre kvinne da jeg var Barbara - for å bruke eksempler fra Den rettferdige. Og ja, jeg skrev faktisk (de aktuelle delene av) denne romanen i fire forskjellige jeg-versjoner før jeg endte med skiftende personal synsvinkel i tredjeperson. 
Førstepersonsfortellinger har klare begrensninger, og det er derfor jeg ofte bytter til tredjeperson i sluttfasen. Å skrive i førsteperson er å sette skylapper på fortellingen: I en jeg-fortelling er det ikke rom for andre perspektiver enn jeg-ets. Alt siles gjennom ham eller henne. Det som for meg kan være en metodisk fordel underveis, er ikke allid en litterær fordel $\mathrm{i}$ teksten som helhet.

\section{Håndhilse, så trenge inn $\mathbf{i}$}

Når jeg er så begeistret for å skrive i førsteperson og roser effektene av hva jeg oppnår med det, forekommer det meg nokså gåtefullt, for ikke å si bakvendt, at jeg i de aller fleste tilfeller påbegynner et nytt romanprosjekt i tredjeperson. For det gjør jeg. Bevegelsen er oftest: tredjeperson - førsteperson - tredjeperson. Jeg har fundert mye på dette. Jeg tror årsaken er at når jeg starter skriveprosessen, kjenner jeg ikke mine litterære personer. Og på paradoksalt vis vil jeg gjerne bli litt kjent med dem før jeg invaderer dem ved å trenge inn i dem og bli dem. Å skrive de første prøvende setningene på en ny tekst gjennom en fremmed persons ord føles rett og slett ubehøvlet. Det høfligste er å bli litt kjent først. Man håndhilser før man penetrerer. Det dreier seg imidlertid ikke bare om kokett høflighet overfor fiktive personer, men også om hva som er mulig. Det dreier seg om det skjønnlitterær skriving er for meg, gradvis å bli kjent med skikkelsene. Ordene som føder nye ord, som bygger skikkelsene, som bor i historien. Som blir en historie.

De få gangene jeg har igangsatt skriveprosessen ved å skrive i førsteperson, har jeg kjent jeg-et godt på forhånd. Ungdomsromanen Fordi jeg elsker deg (2015) er en slik roman. Jeg hadde tenkt mye på hovedpersonen Elin på forhånd, og hun stod ganske klart for meg. Elin hadde jeg gått svanger med så lenge at hun nærmest ble født fiks ferdig. Derfor kunne hun også skrives i førsteperson helt fra begynnelsen. Noe av det aller første jeg skrev, var dette:

Og det begynte, som så mye ellers, ved en tilfeldighet. Jeg møtte Fredrik en fredag. Han stod utenfor butikken nede på hjørnet. Vi hadde sluttet tidligere fordi naturfaglæreren var syk, og vikaren aldri dukket opp. Til slutt kom rektor inn i klasserommet og sa at vi bare kunne begynne helgen. Tina og jeg skulle hjem til henne og drikke te. Vi hadde all verdens tid, og det var varmt til å være september. Tina foreslo at vi skulle kjøpe med oss en liter is. Sjokolade, sa Tina. Jogurtis med cookies! sa jeg.

Dette er avsnittet klippet fra den trykte boken (Uri 2015, s. 7), men forskjellene er minimale (det dreier seg først og fremst om at jeg hadde skrevet at Elin ønsket seg 
krokanis, som jeg endret til jogurtis med cookies etter en utvetydig beskjed fra mine barn om at krokanis er pensjonistis).

Siden jeg ikke kjente Ada og Odd-Erik, startet Stillheten etterpå som en fortelling i tredjeperson. Denne boken har gjennomgått bevegelsen: tredjeperson førsteperson. Stillheten etterpå har to fortellere i førsteperson. Både Ada og Odd-Erik startet i tredjeperson, men de ble forløst i førsteperson.

\section{Det uutsigelige}

Konklusjonen i min egen logg etter å ha byttet kjønnene på lærer og elev, er at det "kjennes riktig". Hva betyr det? Hvorfor "kjennes det riktig" at læreren er en mann og eleven en jente? Hvorfor har jeg skrevet i loggen at navnet Ida "klang ikke riktig", og at Ida er "helt feil faktisk" etterfulgt av hele tre utropstegn?

Gjennom denne teksten forsøker jeg å sette ord på ord. Jeg begynte med å sitere Duras, og her skal jeg igjen trekke frem hennes påstand. Å sette ord på ord er en umulig ting å be en forfatter om. Om det ikke er umulig, er det en fornærmelse. Det eneste en forfatter ønsker, er jo at hennes ord skal være nok i seg selv. Jeg ønsker at de skjønnlitterære verkene er nok. At ordene i dem er tilstrekkelig. At ordene mine skal stå på egne bein. Jeg ønsker ikke at flere ord skal forklare eller supplere ordene mine. Likevel er det nettopp det jeg har forsøkt.

Og av og til finnes det ikke engang noen ord. Jeg vet ikke hvilke jeg skal bruke, for jeg kan verken forklare eller supplere. Hvis det finnes svar, glir de unna. Jeg kan ikke gjøre rede for hvorfor Ada klinger bedre enn Ida som navn på en fiktiv jente. Hvorfor kjenner jeg så sterkt at én vokal er bedre i fremlyd enn en annen vokal? Er det fordi a er en mørk vokal, i en lys? Og at den mørke valøren kler elevskikkelsen bedre? Aner ikke. Her berøres det uforklarlige, det som, uansett hva man ønsker og vil, og uansett om målet er "en eksplisitt refleksjon rundt utviklingen" av et kunstverk, ikke kan uttrykkes på en måte som vil være nyttig eller oppklarende for andre. Det er den ytterste fliken av det som gjør skjønnlitteratur til kunst. Jeg skal ikke forsøke å dra mer i den fliken. Den umulige fliken. Den stikker så vidt frem her og der, i loggen, i min refleksjon rundt det å skrive. Jeg lar den ligge i fred.

\section{Forfatteromtale}

Helene Uri er forfatter ansatt som professor II i skrivekunst ved Norsk barnebokinstitutt. Hun har utgitt rundt tretti bøker i flere sjangre: romaner for voksne, barne- og ungdomsbøker, sakprosa for både voksne og yngre lesere. Bøkene hennes er oversatt til atten språk, og hun har mottatt flere priser, blant annet 
Helene Uri: Jeg håndhilser før jeg penetrerer

Brageprisen (2018). Hennes faglige bakgrunn er språkvitenskap, med nordisk hovedfag (1988) og doktorgrad i anvendt lingvistikk (1996), begge fra Universitetet i Oslo.

\section{Referanser}

Andersen, M. M. (2008). Skriveboka. Oslo: Aschehoug

Duras, M. (2014) [1993], oversatt av Silje Aa. Fagerlund. Å skrive. Oslo: Transfe:r Johansen, A. (2018). Skriv! Håndverk i sakprosa. Oslo: Spartacus

Lukeman, N. (2002). The plot thickens. 8 ways to bring fiction to life. New York: St.Martin's Griffin

Malterud, N. (2012). Kunstnerisk utviklingsarbeid - nødvendig og utfordrende. Nordic Journal of Art and Research, 1(1). https://doi.org/10.7577/information.v1i1.217

Norsk barnebokinstitutt (2019). Kunstnerisk utviklingsarbeid. Hentet 24.10.2019 fra https://barnebokinstituttet.no/kunstnerisk-utviklingsarbeid/

Skomsvold, K. A. (2019). Den andre forsvinninga. Oslo: Oktober

Svingen, A. og Uri, H. (2007). Sommeren vi kledde oss nakne. Oslo: Gyldendal

Svingen, A. og Uri, H. (2012). Din vakre jævel. Oslo: Gyldendal

Tokarczuk, O. (2018) [2012], oversatt av Aldona Szczepanska. Løperne. Oslo: Gyldendal

Uri, H. (2001). Dyp rød 315. Oslo: Gyldendal

Uri, H. (2002). Honningtunger. Oslo: Gyldendal

Uri, H. (2003). Engel av nylon. Oslo: Gyldendal

Uri, H. (2006). De beste blant oss. Oslo: Gyldendal

Uri, H. (2008). Mamma morgenheks. Oslo: Cappelen Damm

Uri, H. (2009). Den rettferdige. Oslo: Gyldendal

Uri, H. (2011). Kjerringer. Oslo: Gyldendal

Uri, H. (2013). Rydde ut. Oslo: Gyldendal

Uri, H. (2015). Fordi jeg elsker deg. Oslo: Cappelen Damm

Uri, H. (2016). Hålke. Oslo: Gyldendal

Uri, H. (2019). Stillheten etterpå. Oslo: Gyldendal

Ørjasæter, K. (2018). Barne- og ungdomslitteratur. Møtet med lesaren. Oslo: Samlaget

Østli, K. (2019). Jon Fosse og hans tre identiteter. A-magasinet 6. september 2019 